\title{
Analysis of the Economically Active Population in the Czech-Polish Border Regions
}

\author{
Karin Gajdová and Pavel Tuleja
}

\begin{abstract}
As the title says, this paper is focused on the Czech-Polish border and economically active population in these regions. Aim of this paper is to evaluate the potential of the labor market and its development in selected regions of the Czech Republic and Poland. It contains an analysis of border regions from a broader perspective. These are regions at NUTS II level, which are along the Czech-Polish border. It is a region Severovýchod, Střední Morava and Moravskoslezsko (Czech Republic) and region of Voivodship Dolnoslezskie, Opolskie and Slezskie (Poland). These are countries that receive maximum support from the European Union for cross-border cooperation. These are countries located in the heart of Europe. These are countries that have a very high potential in all economic, social, transport and other areas, mainly because of the location in the center of Europe.
\end{abstract}

Index Terms-Czech-Polish border, economic active rate, employment rate.

\section{INTRODUCTION}

This paper is focused on the regional labor market and the border regions in the Czech Republic and Poland. In this paper is analyzed regions at the level 2, they are NUTS II regions. It is focused on the NUTS II regions. These are regions Severovýchod, Střední Morava and Moravskoslezsko in the Czech Republic and regions of Voivodeships Dolnoslaskie, Opolskie and Slaskie in Poland. These regions are supported from the European Union. Recently, great emphasis is placed on support cross-border cooperation in the Czech-Polish border, and thus leads to support economic growth of these regions. Czech-Polish border is of great importance and potential, mostly from the location in the center of Europe, that it is a very transit area. Also, the density of population of the area may seem high potential of the area. On the other hand, there are a lot of factors that degradation in this area. And for it it must be supported from national and transnational institutions and organizations.

In this paper there is analysis of labor markets in these regions. Labor markets are very important for other economic factors and other economic development [1]. If the labor market is developed a positive direction, it is very beneficial for other areas. There is some very basic knowledge. If people have jobs, so they have money and if

Manuscript received February 10, 2014; revised April 10, 2014. This paper was supported by the project "Innovation of Educational Programs at Silesian University, School of Business Administration in Karviná" $\mathrm{n}$. CZ.1.07/2.2.00/28.0017.

The authors are with the Department of Economics, School of Business Administration, Silesian University, 73340, Czech Republic (e-mail: gajdova@opf.slu.cz,tuleja@opf.slu.cz). they have money they can spend more money and invest money and it is very beneficial for the whole region and for the whole country. This analysis is focused on the basic indicators such as Employment rate and Economic active population. There are basic calculations which help to show other context. Results are showed in tables and in figures. Finally there is calculation of average growth rate of each selected indicators. This can show development of these indicators.

\section{LITERATURE REVIEW}

The situation on the regional labor market is always affected by both internal and external conditions. Among those outside are in first place overall economic development of the country. The internal factors are both on the labor supply and on the labor demand. Among the internal factors on the labor supply are included its qualitative (e.g. education and health of the population, age structure, length of time in unemployment, mobility) and quantitative characteristics (number of unemployed, number of employed, number of economic active people). On the demand for labor, it is the qualitative point of view characteristic of job vacancies (e.g. qualifications and other requirements for the employee) and quantitative point of view the number of job vacancies. The relationship of supply and demand for labor plays the role of space, qualifying and structural compliance. The overall characteristic of the labor market is also very important rate of market concentration, mainly on the demand for labor. If only a few dominant firms or a few industries may be regional labor market significantly more sensitive to the loss of production in the sector. When the variability of the economy it is extremely important to flexibly and quickly to labor markets in different regions can adapt to new conditions. Regions adapt in different ways and thus regional disparities are created [2]. Particularly in this connection with labor market that are regional disparities in the labor market.

We chose the same approach to this issue. In this paper we focused on the analysis of basic labor market indicators, through which we will in the following article to evaluate the potential of regional labor markets. Ref. [3] these are the basic indicators describing the developments of the labor markets, so we are focused on these two summarizing aggregates, they are Employment rate and Economic active rate.

\section{A. Methodology and Data}

In terms of regional comparison is a very important indicator appears to the employment rate [4]. The employment rate shows the share of employed in the total adult population of the region (people 15 years and over). It 
logically follows that the value of this macroeconomic aggregate is determined using the following equation (1).

$$
e=\frac{E}{A P} \times 100
$$

where

$$
\begin{aligned}
& e=\text { employment rate } \\
& E=\text { number of employees } \\
& A P=\text { adult population }
\end{aligned}
$$

Another indicator to which it focuses the attention is Economic active rate. It is also called rate of participation. It is indicator that shows the share of economically active population of the adult population (i.e. total number of people), in that period was at least fifteen years of age, as in (2).

$$
m=\frac{E A P}{A P} \times 100
$$

where

$m=$ economic active rate

$E A P=$ economic active population

$A P=$ adult population

For our analysis we chose these two mentioned indicators, because we considered them to be sufficiently exhibiting indicators for the concept of regional labor markets and comparisons between these regions. For a more detailed overview can be subsequently analyzed many other indicators, but it will be part of further research. With these indicators (employment rate and economic active rate) we have worked on and we examined them in detail through the basic analytical calculations.

It has been calculated annual changes in selected indicators in the regions. The change in the selected indicators expresses the \% change in the indicator in the monitored period compared to the same period last year.

$$
g_{x ; n}=\frac{e_{x ; t}-e_{x ; t-1}}{e_{x ; t-1}} \times 100
$$

where

\section{$g=$ growth, annual changes}

Subsequently, it was calculated the average growth rate of selected indicator [5]. We measure the average rate of growth by the geometric average of annual growth rates.

$G\left(g_{x ; 1}, g_{x ; 2}, \ldots, g_{x ; n}\right)=\sqrt[n]{g_{x ; 1}, g_{x ; 2}, \ldots, g_{x ; n}}=\left(\prod_{i=1}^{n} g_{x ; i}\right)^{\frac{1}{n}}$

where

$G=$ average growth rate of selected indicator

\section{SELECTED COUNTRIES AND THEIR BORDERLAND}

The research deals with regions in the two European countries (the Czech Republic and Poland). These are countries that receive maximum support from the European Union for cross-border cooperation. These are countries located in the heart of Europe. These are countries that have a very high potential in all economic, social, transport and other areas, mainly because of the location in the center of Europe. And their regions on the common borders have even greater potential [6]. On the contrary they have a lot of problems and their economic development is not too beneficial.

The Czech Republic is from statistical view of the European Union divided into 14 regions at level 3 (NUTS III) and furthermore into 8 cohesion regions at level 2 (NUTS II). Poland is from statistical view of European Union divided to 66 subregionsat level 3 (NUTS III) and furthermore to 16 voivodeshipsat level 2 (NUTS II).

For our analysis we chose regions at the level number 2, they are regions NUTS II. We chose 3 border regions NUTS II in the Czech Republic and 3 border regions NUTS II in Poland. These are regions NUTS II which only have a common border of these two countries [7]. It is showed in the Fig. 1.

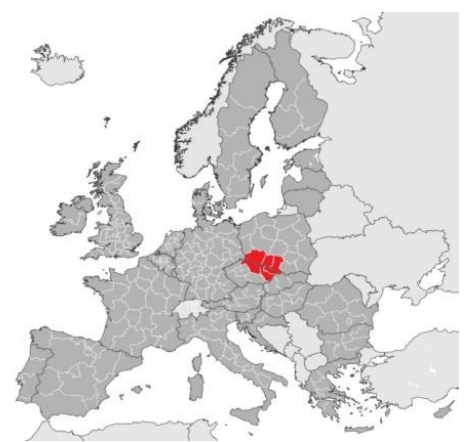

Fig. 1 a). Selected NUTS II regions in European Union (in the Czech Republic and Poland).

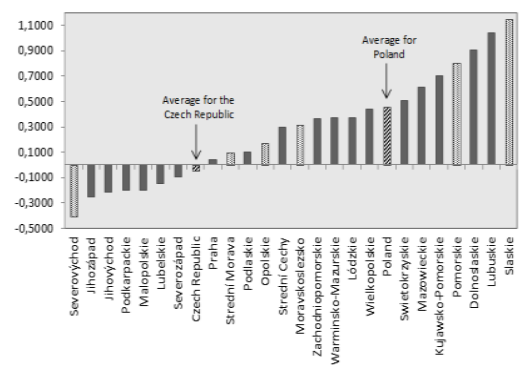

Fig. 1 b). Average growth rate of the employment by NUTS 2 regions in the Czech Republic and in Poland.

This figure shows regions NUTS II which are selected for our analysis and they have greatest potential for other positive development. These regions are supported from the European Union. These are regions Severovýchod, Střední Morava and Moravskoslezsko in the Czech Republic and regions of Voivodeships Dolnoslaskie, Opolskie and Slaskie in Poland.

European territorial cooperation is concentrated on promote joint solving of problems, development of cross-border economic and social activities through joint strategies for sustainable territorial development. And furthermore it is concentrated on support of cross-border integration of labor markets, local employment and other.

\section{EMPIRIC ANALYSIS}

Special opportunities for social and economic 
development of the Czech - Polish border are its advantageous geographical location in central Europe. Ref. [8] another possibility of external relations Czech-Polish border, in areas such as scientific research and development of new technology, is giving a smalldistance from the metropolitan area of Prague, Wroclaw, Brno, Katowice, Kraków, Bratislava, Berlin and Vienna.

The priority development activities should become appropriate interregional policy, which will consist in strengthening external relations territory. These will contribute to the strengthening of cooperative relations and greater availability of external markets, causing inflow of foreign direct investment and tourism development [9].

The absence of appropriate policy measures aimed at strengthening external cohesion may lead to negative phenomena in the area, i.e. structural unemployment, development social pathology, the depopulation of regions, reducing its competitiveness in comparison with other European regions.

The competent lobbing Czech-Polish borderland in the use of endogenous potential to contribute to the growth of the region's competitiveness based on human resources and driver of innovation and knowledge.

\section{A. Employment}

TABLE I: EMPLOYMENT RATE BY SELECTED NUTS2 REGIONS (\%)

\begin{tabular}{|c|c|c|c|c|c|c|c|}
\hline & 2000 & 2002 & 2004 & 2006 & 2008 & 2010 & 2012 \\
\hline $\begin{array}{l}\text { European } \\
\text { Union } 28\end{array}$ & 51.5 & 51.3 & 51.3 & 52.8 & 53.6 & 51.9 & 51.7 \\
\hline $\begin{array}{l}\text { Czech } \\
\text { Republic }\end{array}$ & 54.8 & 55.3 & 54.1 & 55.0 & 55.9 & 54.2 & 54.5 \\
\hline Praha & 59.7 & 60.4 & 58.9 & 60.3 & 60.2 & 59.9 & 60.0 \\
\hline StredníCechy & 55.6 & 57.5 & 56.2 & 57.1 & 58.0 & 56.6 & 57.6 \\
\hline Jihozápad & 57.2 & 57.1 & 55.9 & 56.6 & 57.8 & 55.3 & 55.5 \\
\hline Severozápad & 52.1 & 53.6 & 53.5 & 53.0 & 53.6 & 52.1 & 51.5 \\
\hline Severovýchod & 56.1 & 56.3 & 54.7 & 55.4 & 55.3 & 53.6 & 53.4 \\
\hline Jihovýchod & 55.1 & 54.1 & 53.3 & 53.9 & 55.1 & 53.8 & 53.7 \\
\hline $\begin{array}{l}\text { Strední } \\
\text { Morava }\end{array}$ & 52.5 & 52.9 & 52.2 & 53.9 & 54.6 & 51.3 & 53.1 \\
\hline $\begin{array}{l}\text { Moravskoslez } \\
\text { sko }\end{array}$ & 49.9 & 50.9 & 48.9 & 50.5 & 53.1 & 50.9 & 51.8 \\
\hline Poland & 47.5 & 44.6 & 44.0 & 49.6 & 50.4 & 50.4 & 50.2 \\
\hline Lódzkie & 48.1 & 45.2 & 43.9 & 50.9 & 51.6 & 51.5 & 50.3 \\
\hline Mazowieckie & 51.5 & 47.8 & 46.2 & 53.5 & 55.3 & 54.2 & 55.4 \\
\hline Malopolskie & 50.7 & 48.6 & 47.2 & 51.4 & 50.3 & 50.1 & 49.5 \\
\hline Slaskie & 42.2 & 40.7 & 41.7 & 46.1 & 48.3 & 48.1 & 48.4 \\
\hline Lubelskie & 51.5 & 49.5 & 46.5 & 52.5 & 50.4 & 50.7 & 50.6 \\
\hline Podkarpackie & 50.0 & 48.2 & 44.5 & 49.8 & 50.2 & 50.3 & 48.8 \\
\hline $\begin{array}{l}\text { Swietokrzyski } \\
\text { e }\end{array}$ & 46.7 & 42.4 & 42.4 & 50.2 & 51.6 & 50.1 & 49.6 \\
\hline Podlaskie & 50.0 & 47.6 & 48.0 & 52.1 & 51.1 & 49.2 & 50.6 \\
\hline Wielkopolskie & 49.7 & 46.1 & 47.5 & 51.0 & 51.6 & 53.1 & 52.4 \\
\hline $\begin{array}{l}\text { Zachodniopo } \\
\text { morskie }\end{array}$ & 44.5 & 39.3 & 41.5 & 45.1 & 45.6 & 46.2 & 46.5 \\
\hline Lubuskie & 43.1 & 40.8 & 41.2 & 48.3 & 49.0 & 49.8 & 48.8 \\
\hline Dolnoslaskie & 42.9 & 40.8 & 39.4 & 47.8 & 48.1 & 48.5 & 47.8 \\
\hline Opolskie & 48.2 & 43.7 & 41.4 & 48.5 & 47.9 & 48.5 & 49.2 \\
\hline $\begin{array}{l}\text { Kujawsko-Po } \\
\text { morskie }\end{array}$ & 45.6 & 43.0 & 45.4 & 46.7 & 47.7 & 48.9 & 49.6 \\
\hline $\begin{array}{l}\text { Warminsko- } \\
\text { Mazurskie }\end{array}$ & 43.8 & 38.9 & 39.1 & 46.1 & 47.5 & 48.3 & 45.8 \\
\hline Pomorskie & 45.6 & 44.2 & 42.3 & 48.1 & 49.8 & 50.7 & 50.2 \\
\hline
\end{tabular}

Statistic of labor market occupies an important place in many EU policies, and after the 1997 Treaty of Amsterdam included a chapter on employment. The employment rate or the proportion of the working age population, who are in employment, is seen as a key social indicator for analysis in examining the evolution of the labor market [10]. The higher the value of this indicator, the more positive situation is there.

First interesting indicator for our analysis is employment rate. The way to determine this indicator has been shown in chapter II. Specific values of the indicators in the regions NUTS II are shown in Table I. There are selected regions, important regions for our analysis (6 regions NUTS II) and other regions in selected countries for comparison.

First we look at the evolution of employment rate in the European Union (it is average for all 28 countries - it included also Croatia, recently added country) and in the Czech Republic and Poland. The development of employment in the Czech Republic is in monitored period at higher level than in the European Union (average). The process of development is almost balanced it is in the Czech Republic and in the European Union. On the contrary in Poland there is the process of development more abrupt. The lowest employment was in 2003 and 2004 and after it employment raised. But still employment rate is lower than in the Czech Republic and in the European Union.

In the case of the Czech Republic regions evolved in different ways. The lowest values in the period were recognized in region Moravskoslezsko. The development in this region is the lowest in the comparison with all other regions in the Czech Republic. This is one of the regions in the border with Poland. But value gradually increases.

In contrast in the other monitored region Severovýchod this value gradually declines. And in the region Stredni Morava there is development stagnant.

In the case of Poland regions evolved in different ways too. The lowest values in the period were recognized in region Zachodniopomorskie, region Warminsko-Mazurskie and in region Dolnoslaskie. Dolnoslaskie region is one of the regions in the border with the Czech Republic.

In other observed regions are also at the level under average of Poland. The development in Opolskieregion is little better than the development in Slaskie region.

From the development of employment rate it was calculated the average growth rate of employment. The Fig. 1 b) shows average growth rate of the Employment by NUTS 2 regions in the Czech Republic and in Poland.

This figure shows average growth rates for both countries for the Czech Republic and Poland. It is very interesting that we found that the development of employment (and total value of this indicator in monitored period) in the Czech Republic is higher than in Poland and the average growth rate is higher in Poland than in the Czech Republic. The average growth rate in Poland is $0.46 \%$ and in the Czech Republic is $-0.045 \%$. It means employment rate in the Czech Republic is declining and in Poland is rising.

When we look at 6 observed bordering regions we see the worst development (average growth rate) is in region Severovýchod and the best development (average growth rate) is in region Slaskie.

When we evaluate the overall analysis of the employment rate in border regions NUTS II we find out some certain facts 
and context.

The development of employment rate in monitored period from 2000 to 2012 is the worst in region Moravskoslezsko (in the Czech Republic) and in region Dolnoslaskie (in Poland) and the similar results are in comparison of value of employment rate in 2012. The worst value is in region Moravskoslezsko (in the Czech Republic) and in region Dolnoslaskie (in Poland). On the contrary when we look at average growth rate of employment the worst situation is in region Severovýchod (in the Czech Republic) and in region Opolskie (in Poland).

\section{B. Economically Active People}

In terms of position in the economic process it distinguishes economically active population and economically inactive population. Economically active population is very important for economic level of regions. We chose other important indicator and it is economic active rate. Logically values of this indicator are higher than values of previous indicator.

TABLE II: ECONOMIC ACTIVE RATES BY SELECTED NUTS2 REGIONS (\%)

\begin{tabular}{l|c|c|c|c|c|c|c}
\hline \hline & $\mathbf{2 0 0 0}$ & $\mathbf{2 0 0 2}$ & $\mathbf{2 0 0 4}$ & $\mathbf{2 0 0 6}$ & $\mathbf{2 0 0 8}$ & $\mathbf{2 0 1 0}$ & $\mathbf{2 0 1 2}$ \\
\hline $\begin{array}{l}\text { European } \\
\text { Union 28 }\end{array}$ & 56.7 & 56.4 & 56.5 & 57.5 & 57.6 & 57.5 & 57.7 \\
\hline $\begin{array}{l}\text { Czech } \\
\text { Republic }\end{array}$ & 60.1 & 59.5 & 59.0 & 59.3 & 58.5 & 58.4 & 58.6 \\
\hline Praha & 62.2 & 62.6 & 61.3 & 62.0 & 61.4 & 62.2 & 62.0 \\
\hline StredníCechy & 60.2 & 60.3 & 59.4 & 59.8 & 59.6 & 59.7 & 60.4 \\
\hline Jihozápad & 60.9 & 60.0 & 59.4 & 59.5 & 59.7 & 58.5 & 58.6 \\
\hline Severozápad & 61.3 & 60.5 & 60.8 & 60.8 & 58.2 & 58.6 & 57.6 \\
\hline Severovýchod & 60.2 & 59.3 & 58.6 & 59.0 & 57.7 & 57.6 & 58.0 \\
\hline Jihovýchod & 59.3 & 58.0 & 57.9 & 58.0 & 57.4 & 58.1 & 58.1 \\
\hline $\begin{array}{l}\text { Strední } \\
\text { Morava }\end{array}$ & 58.9 & 57.8 & 57.9 & 58.4 & 57.4 & 56.2 & 57.4 \\
\hline $\begin{array}{l}\text { Moravskoslez } \\
\text { sko }\end{array}$ & 58.1 & 58.1 & 57.3 & 57.3 & 57.3 & 56.7 & 57.2 \\
\hline Poland & 56.8 & 55.7 & 54.4 & 57.6 & 54.2 & 55.8 & 55.9 \\
\hline Lódzkie & 57.4 & 56.7 & 54.0 & 58.8 & 55.3 & 56.8 & 56.6 \\
\hline Mazowieckie & 59.5 & 57.4 & 55.0 & 61.0 & 58.9 & 58.5 & 60.3 \\
\hline Malopolskie & 57.4 & 57.6 & 56.8 & 58.7 & 53.6 & 55.1 & 55.3 \\
\hline Slaskie & 52.0 & 51.1 & 51.2 & 53.8 & 51.7 & 52.9 & 53.5 \\
\hline Lubelskie & 59.6 & 59.1 & 55.5 & 60.2 & 55.3 & 56.3 & 56.5 \\
\hline Podkarpackie & 58.4 & 58.9 & 52.4 & 57.7 & 54.7 & 56.9 & 56.3 \\
\hline $\begin{array}{l}\text { Swietokrzyski } \\
\text { e }\end{array}$ & 56.3 & 52.2 & 53.2 & 59.4 & 56.6 & 57.0 & 57.1 \\
\hline Podlaskie & 59.4 & 56.7 & 56.3 & 58.8 & 54.6 & 54.9 & 55.7 \\
\hline Wielkopolskie & 57.9 & 56.7 & 57.4 & 58.4 & 55.0 & 58.2 & 57.3 \\
\hline $\begin{array}{l}\text { Zachodniopo } \\
\text { morskie }\end{array}$ & 55.9 & 53.7 & 54.5 & 54.4 & 50.4 & 52.7 & 52.2 \\
\hline Lubuskie & 54.8 & 55.1 & 54.8 & 56.2 & 52.4 & 55.7 & 53.7 \\
\hline Dolnoslaskie & 55.4 & 54.7 & 53.7 & 57.8 & 52.9 & 54.7 & 53.8 \\
\hline Opolskie & 56.4 & 55.3 & 51.3 & 56.1 & 51.2 & 53.7 & 54.3 \\
\hline $\begin{array}{l}\text { Kujawsko-Po } \\
\text { morskie }\end{array}$ & 55.7 & 55.4 & 58.3 & 55.8 & 52.5 & 54.7 & 56.3 \\
\hline $\begin{array}{l}\text { Warminsko- } \\
\text { Mazurskie }\end{array}$ & 56.4 & 53.5 & 51.3 & 54.8 & 51.3 & 53.5 & 51.4 \\
\hline Pomorskie & 55.0 & 55.9 & 52.8 & 55.8 & 52.7 & 55.9 & 55.5 \\
\hline \hline
\end{tabular}

When we compare selected countries with European Union (average of European Union) we find out the development of economic active rate is almost balanced in the Czech Republic and in the European Union [11]. But in the Czech Republic there we can see problem because economic active rate is declining (from $60.1 \%$ to $58.6 \%$ ), on the other hand in the all European Union it is rising (from $56.7 \%$ to $57.7 \%$ ). In Poland there the process of the development is more abrupt. The largest jump is between 2005 and 2006. But in whole monitored period the development is declining too (from $56.8 \%$ to $55.9 \%$ ). It shows Table II.

In the case of the Czech Republic the development of economically active people is the worst in region Moravskoslezsko and in region Stredni Morava. Both regions are border regions with Poland.

In the case of Poland the development of economic active rate is the worst in region Zachodniopomorskie, in region Warminsko-Mazurskie and in region Slaskie. This region, region Slaskie, is border region with the Czech Republic.

Other figures show economic active rates in last monitored year, i.e. in 2012. The Fig. 2 a) shows the situation in the Czech Republic in 2012 and the Fig. 2 b) shows the situation in Poland in 2012.

It is evident the situation in border regions is not good. Though it shows similar situation like in previous indicator this situation is more different in one way. In previous indicator there was the smallest value in region Severozápad, now the smallest value is in region Moravskoslezsko. There is economic active rate with value $57.2 \%$.

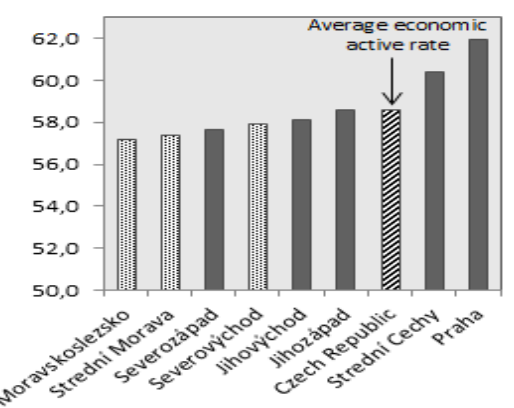

Fig. 2 a) Economic active rate by NUTS 2 regions in the Czech Republic in 2012.

In other Fig. 2 b), there is shown situation in Poland. There monitored regions, i.e. regions in the border with the Czech Republic, are below average economic active rate of Poland too. The smallest value of average economic active rate is in region Slaskie $53.5 \%$.

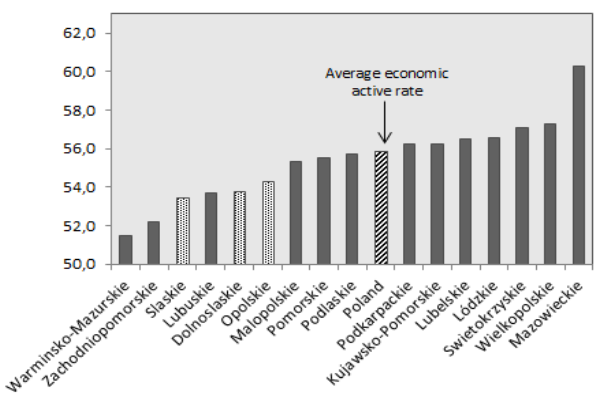

Fig. 2 b). Economic active rate by NUTS 2 regions in Poland in 2012.

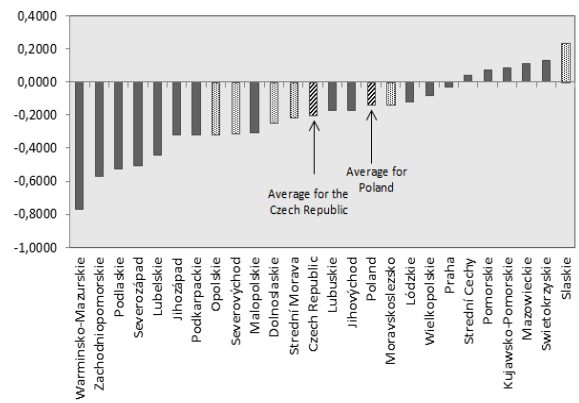

Fig. 3. Average growth rate of the economic active by NUTS 2 regions in the Czech Republic and in Poland. 
In last figure there is comparison of average growth rate of economic active rates. Fig. 3shows average growth rate of the economic active by NUTS 2 regions in the Czech Republic and in Poland. All of it is in one figure.

It is evident mainly values of average growth rates are negatives. It means rates of economic activity are declining. It may be due to emigration of economic active people, for example. The worst value of average growth rate is in region Opolskie (in Poland), i.e. $-0.32 \%$ and in region Severovýchod (in the Czech Republic), i.e. $-0.31 \%$. And the highest value of average growth rate is in region Slaskie (in Poland), i.e. $0.23 \%$. Averages of growth rates in both countries are in similar level (-0.19\% and $-0.13 \%)$.

When we evaluate the overall analysis of the economic active rate in border regions NUTS II we find out some other certain facts and context.

The worst development of economic active rates in observed regions is in region Moravskoslezsko (in the Czech Republic) and in region Slaskie (in Poland). The similar results are when we look at situation in last monitored year, in 2012. The smallest value of economic active rate is in region Moravskoslezsko and in region Slaskie. And finally we calculated the average growth rate of economically activity and there is evident the smallest value is in region Opolskie (in Poland) and in region Severovýchod (in the Czech Republic).

\section{CONCLUSION}

Finally, here is summarizing of important information which is identified in this article. In the paperthere was a basic analysis of two key indicators of the labor market. This is the Employment rate and Economic active rate. This article focuses on six specific regions of the two countries, country Czech Republic and Poland. These are regions that are along the common border between the Czech Republic and Poland. On the area there isfocusing the attention of national governments and local public administration as well as the European Union. That is an area with considerable potential but also with problems that hinder economic development.

The attention should be given to the region Moravskoslezsko in the Czech Republic and to the region Dolnoslaskie in Poland.

Finally of analysis of selected indicators there were calculated average growth rates of indicators. From it is evident the slowest average growth rates are in region Severovýchod in the Czech Republic and in region Opolskie in Poland.

This paper was supported by the project "Innovation of Educational Programs at Silesian University, School of Business Administration in Karviná" n. CZ.1.07/2.2.00/28.0017.

\section{REFERENCES}

[1] P. Nijkamp, R. L. Moomaw, and J. Traistaru-Siedshclag, Entrepreneurship investment and spatial dynamics: Lessons and implications for the enlarged EU, Cheltenham, UK: E. Elgar Pub., p. 238,2006

[2] K. Fojtíková and P. Tuleja. "Demographic progression of the Moravian-Silesian region," in Proc. the 10th International Scientific Conference Economic Policy in the European Union Member Countries, Karviná: Silesian University, pp. 66-76, 2013.

[3] I. Majerova. "International development cooperation of the Czech Republic in the context of European development," Prague Economic Papers, vol. 21, pp. 166-185, June 2012.

[4] R. Hušek, Aplikovanáekonometrie, $1^{\text {st }}$ ed., Praha: VŠE, p. 270, 2001.

[5] M. Tvrdon̆ and T. Verner, "Examining the relationship between economic performance and unemployment: the case of Visegrad countries," in Proc. the 29th International Conference on Mathematical Methods in Economics 2011, Jánska Dolina: University of Economics, pp. 733-738, 2011.

[6] A. Kutscherauer, H. Fachinelli, J. Sucháček, K. Skokan. M. Hučka. P. Tuleja, and P. Tománek, Regionální disparity: Disparity $v$ regionálnímrozvojizemě. jejichpojetí. identifikace a hodnoceni, $1^{\mathrm{st}} \mathrm{ed}$, Ostrava: VŠB-TU, pp. $46-48,2010$.

[7] K. Gajdová and P. Tuleja, "Indicator of labor market in the Czech Republic and Poland: Focused on the border regions NUTS II," in Proc. the $4^{\text {th }}$ International Conference on Applied Social Science in Singapore.

[8] OECD. (September 2013). Regional Development. [Online]. Available: http://www.oecd.org/gov/regional-policy/regionaldevelopment.htm.

[9] R. J. Stimson, R. R. Stough, and B. H. Roberts, Regional Economic Development: Analysis and Planning Strategy, Revised edition, Berlin: Springer, 2006.

[10] K. Gajdová and P. Tuleja, "Regional disparities in the european union: Focused on the wages and their development," in Proc. the 3rd International Conference on Economics, Trade and Development in Bangkok, Thailand, Hong Kong: IEDRC, pp. 262-266, 2013.

[11] J. Čadil, Regionálníekonomie, Regional Economics, Prague: C. H. Beck, 2010.

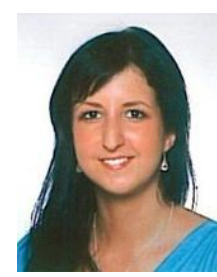

K. Gajdová was born in Ostrava in the Czech Republic on the $21^{\text {st }}$ of June 1986. She studied business academy in Ostrava and then she studied at the Silesian University in Opava. School of Business Administration in Karvina. Now she is Ph.D. candidate whereas she is employed as academic staff at the Silesian University. She also works for the Regional Development Agency. it is an institution dedicated to the development of Moravian-Silesian Region.

She deals with the regional disparities national economies and business economy. She has published many articles during her studies and work, for example: "Unemployment in the European Union context with selected indicators in 2010". "Changes in selected characteristics of the EU labour market in times of economic crisis" - these papers were presented at a conference in Barcelona. Spain and these papers are in database Web of Science.

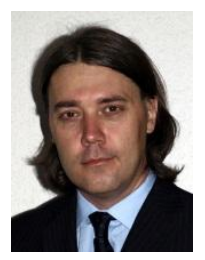

P. Tuleja was born in Ostrava in the Czech Republic on the $31^{\text {st }}$ of March 1971. He studied at the VŠB-Technical University of Ostrava. In 2008 he graduated successfully facilitation and he is associate professor now. And now he is prepares for getting the title Prof. Immediately after the study began working at the Silesian University in Opava. School of Business Administration in Karvina. Department of economics. Since 2010 he is head of department of economics. And since January 2013 he is the dean of the School of Business Administration in Karvina.

$\mathrm{He}$ is respected expert in the field of economic policy and governance. Moreover he works in other public institutions. For example he is member of Committee of the Social Council of Moravian-Silesian Region, a member of the Expert Group for Strategy of Development of Moravian-Silesian Region and so on.

Whereas he works at the Silesian University he authored more than 180 publications in the field of economics policy. etc. 